Syntax Literate: Jurnal Ilmiah Indonesia p-ISSN: 2541-0849

e-ISSN : 2548-1398

Vol. 6, No. 10, Oktober 2021

\title{
PENGARUH CITRA MEREK, KESADARAN MEREK DAN E-WOM TERHADAP MINAT BELI OBAT JAMU MASUK ANGIN BEJO JAHE MERAH DI INDONESIA
}

\section{Christarevy Renaputra Hosfiar, Miguna Astuti, Acim Heri Iswanto}

Universitas Pembangunan Nasional (UPN) Veteran Jakarta, Indonesia

Email: christarevy@gmail.com, miguna.astuti@upnvj.ac.id, h.iswanto@upnvj.ac.id

\begin{abstract}
Abstrak
Penelitian ini menganalisis minat beli terhadap obat jamu masuk angin produk BEJO Jahe Merah di Indonesia. BEJO Jahe Merah merupakan obat jamu masuk angin herbal dengan memakai jahe merah yang diproduksi untuk menyehatkan atau menjaga daya tahan tubuhnya termasuk dengan obat jamu masuk angin. Penelitian ini memiliki tujuan untuk memahami hal-hal yang berpengaruh pada minat beli Bejo Jahe Merah di Indonesia. Penelitian ini meliputi pengaruh citra merek, kesadaran merek dan e-word of mouth. Pendekatan deskriptif dan inferensial digunakan pada penelitian ini. Peneliti memakai jenis data berupa data kuantitatif serta menggunakan sumber data primer dan sekunder. 385 orang terlibat dalam penelitian ini sebagai sampel, yang merupakan konsumen BEJO Jahe Merah dengan menggunakan teknik convenience sampling. Data dikumpulkan dengan menggunakan e-kuesioner (google form) yang disebarkan secara online melalui jejaring sosial. Teknik analisis data diolah menggunakan Partial Least Square (PLS). Hasil analisis data menunjukkan bahwa: (1) Citra Merek memiliki pengaruh signifikan terhadap Minat Beli Obat Jamu Bejo Jahe Merah (2) Kesadaran Merek tidak berpengaruh signifikan terhadap Minat Beli Obat Jamu Bejo Jahe Merah (3) E-WOM tidak berpengaruh signifikan terhadap Minat Beli Obat Jamu Bejo Jahe Merah. Kesimpulan dari hasil penelitian Citra Merek dan E-WOM memiliki pengaruh signifikan terhadap Minat Beli Obat Jamu Bejo Jahe Merah sedangkan Kesadaran Merek tidak mempunyai pengaruh secara signifikan.
\end{abstract}

Kata Kunci: citra merek; kesadaran merek; e-word of mouth; minat beli

\section{Abstract}

This study analyzed the buying interest on the herbal cold medicine of BEJO Red Ginger in Indonesia. BEJO Red Ginger is a herbal cold medicine using red ginger which is produced to nourish or maintain the immune system. This study aimed to understand the influential factors of the buying interest of Bejo Red Ginger in Indonesia. This research involved the influence of brand image, brand awareness and e-word of mouth. Descriptive and inferential approaches were applied in this study. Researchers used data types in the form of quantitative data and used primary and secondary data sources. 385 people who were consumers of BEJO Red Ginger were selected in this study as a sample through convenience sampling technique. Data were collected using an e-questionnaire (google form) which were 
distributed online through social networks. The data analysis technique was processed using Partial Least Square (PLS). The results of data analysis indicated that: (1) Brand Image has a significant effect on Purchase Intention of Bejo Red Ginger Herbal Medicine (2) Brand Awareness has no significant effect on Purchase Intention of Bejo Red Ginger Herbal Medicine (3) E-WOM has no

Keywords: brand image; brand awareness; e-word of mouth; purchase intention

Received: 2021-09-20; Accepted: 2021-10-05; Published: 2021-10-20

\section{Pendahuluan}

Di zaman modern seperti ini konsumen sudah semakin pintar dalam memilih obat yang akan dikonsumsi untuk menyehatkan atau menjaga daya tahan tubuhnya termasuk dengan obat jamu masuk angin. Obat jamu masuk angin cair kemasan sachet menjadi pilihan instant bagi konsumen yang merasa badannya tidak sehat atau masuk angin (Kabaressy \& DW, 2017).

Perilaku konsumen yang semakin pintar dalam memilih obat tersebut yang akan dikonsumsinya membuat persaingan bisnis obat jamu masuk angin semakin ketat. Industri consumer goods yang tidak mampu mengantisipasi persaingan ini akan dikalahkan oleh para pesaingnya. Kondisi ini yang harus dihindari oleh perusahaan yang memproduksi obat jamu masuk angin. Dari berbagai merek yang dikeluarkan dari perusahaan berbeda terdapat tiga obat jamu masuk angin teratas yaitu Tolak Angin, Antangin, BEJO Jahe Merah. Saat ini, telah banyak beredar merek obat jamu masuk angin di pasaran. Hal ini menambah peluang kebebasan bagi konsumen untuk menentukan produk obat jamu masuk angin yang akan dikonsumsi (Iskandar \& Mustamu, 2018). Berikut ini grafik perkembangan konsumen dalam memilih produk obat jamu masuk angin.

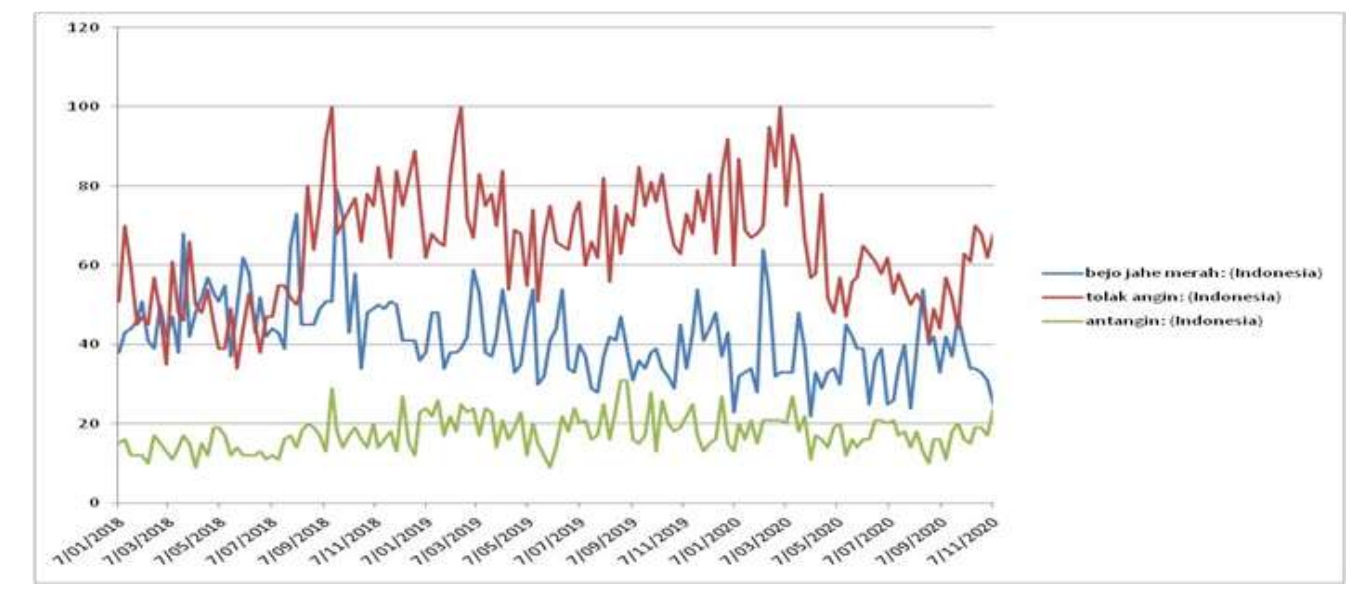

Gambar 1

Grafik Perkembangan Konsumen Dalam Memilih Produk Obat Jamu Masuk Angin Tahun 2018 - 2020

Sumber: https://trends.google.co.id/trends/explore?date $=2020$ 
Berdasarkan gambar 1 diatas, dapat dilihat perkembangan konsumen dalam memilih produk obat jamu masuk angin. Pada tahun 2018 Bejo Jahe Merah mengalami peningkatan yang signifikan terutama di bulan Mei - Juli 2018 dan September 2018. Pada tahun 2019 Bejo Jahe Merah mengalami penurunan dibanding tahun sebelumnya dari Januari 2019 - Desember 2019. Pada tahun 2020 Bejo Jahe Merah mengalami peningkatan pada bulan Juli, September dan November 2020. Hal tersebut memperlihatkan fluktuasi minat konsumen dalam membeli Bejo Jahe Merah. Padahal data google trend yang sama menunjukkan trend tertinggi Produk Bejo Jahe Merah terkait kategori minat konsumen dalam obat jamu masuk angin. Hal ini mengindikasikan adanya permasalahan minat beli pada Bejo Jahe Merah.

Selain data dari gambar 1 diatas terdapat pula data yang diperoleh dari Top Brand Award Indonesia terkait perbandingan produk jamu masuk angin tahun 20182020, sebagai berikut:

Tabel 1

Top Brand Award Jamu Masuk Angin Tahun 2018 - 2020

\begin{tabular}{clccc}
\hline No & \multicolumn{1}{c}{ Merek } & 2018 & 2019 & 2020 \\
\hline 1 & Tolak Angin Sidomuncul & $53.50 \%$ & $53.10 \%$ & $48.30 \%$ \\
\hline 2 & Antangin & $42.40 \%$ & $38.90 \%$ & $40.60 \%$ \\
\hline 3 & Bintang Toedjoe & $1.00 \%$ & $4.50 \%$ & $5.00 \%$ \\
\hline
\end{tabular}

Sumber: https://www.topbrand-award.com/top-brand-index/

Dilihat dari tabel 1 diatas bahwa produk jamu masuk angin bintang Toedjo memiliki posisi ke 3 dari Top Brand Award diatas dengan demikian memiliki persentase yang meningkat setiap tahunnya namun persentase yang dimiliki sangat rendah diatas produk lainnya yaitu pada tahun 2018 memiliki persentase 1\% pada tahun 2019 meningkat menjadi $4.50 \%$ dan pada tahun 2020 meningkat menjadi 5\%. Data Top Brand tersebut semakin memperkuat indikasi permasalahan minat beli.

Banyak faktor yang dapat memberi pengaruh pada minat beli, salah satunya yaitu E-WOM. Minat beli sangat dipengaruhi oleh E-WOM, sebab bila E-WOM pada suatu produk itu positif atau meningkat akan berbanding lurus dengan minat beli (Duarte, Costa e Silva, \& Ferreira, 2018). Selain itu EWOM mempunyai peran kuat yaitu sosial media seperti data google trend tersebut yang berkaitan dengan karakteristik konsumen seperti usia, jenis kelamin, pendapat dan status sosial yang pada akhirnya mempengaruhi minat beli (Park, Hyun, \& Thavisay, 2021).

Selain EWOM, citra merek juga menjadi faktor lain yang dapat memberi pengaruh pada minat beli. Dikatakan bahwa citra merek bisa memberi pengaruh langsung terhadap minat beli konsumen (Wu, Yeh, \& Hsiao, 2011). Selain itu, tinggi atau rendahnya citra merek dan kesadaran merek berhubungan langsung dengan minat beli konsumen terhadap suatu produk (Graciola, De Toni, Milan, \& Eberle, 2020). Data pada tabel 1 mengindikasikan bahwa citra merek mempunyai pengaruh terhadap minat beli karena di tabel ditunjukkan Bejo masih menempati terbawah yaitu hanya kisaran 
10\% dari tahun 2018 - tahun 2020 dan pada durasi tersebut terlihat bahwa trend yang mengindikasikan minat beli juga fluktuatif.

Kesadaran merek juga menjadi faktor lain yang mempengaruhi minat beli. Kesadaran merek secara definisi dapat diartikan sebagai kemampuan merek untuk muncul pada pikiran pertama yang melintas di ingatan konsumen kala memikirkan suatu produk dan bagaimana mudahnya merek tersebut dikeluarkan (Kotler \& Keller, 2016). Apabila kesadaran konsumen akan suatu merek positif, maka minat konsumen tersebut dalam membeli akan sebanding pula. Dengan kata lain, bila kesadaran merek positif maka minat beli positif (Seongseop (Sam) Kim, Choe, \& Petrick, 2018). Hal serupa juga disampaikan pada penelitian lain, dimana kesadaran merek secara signifikan dapat berpengaruh terhadap minat beli (Dabbous \& Barakat, 2020).

Minat beli juga dapat dipengaruhi oleh promosi. Dalam mewujudkan tujuan penjualan, promosi menjadi faktor penting, terutama untuk menguasai pangsa pasar. Dengan mencoba atau memeriksa barang-barang yang dihasilkan oleh perusahaan terlebih dahulu, konsumen bisa menjadi pelanggan tetap. Namun, hal tersebut akan menjadi berbeda ketika konsumen kurang yakin dengan barang-barang itu. Maka dari itu, diperlukan adanya promosi yang terarah, dengan tujuan untuk memberikan kesan positif agar penjualan dapat meningkat (Mardalena, Lubis, \& Utami, 2018).

Salah satu promosi yang paling efektif pada saat ini ialah melalui E-WOM EWOM yaitu suatu bentuk komunikasi yang didefinisikan sebagai afirmasi dari konsumen potensial, konsumen aktual, ataupun eks pelanggan mengenai produk atau perusahaan, melalui media internet yang diciptakan untuk banyak orang maupun lembaga (Anggitasari, Hurriyati, \& Wibowo, 2017). Beberapa riset bahkan menunjukkan bahwa $E$-WOM dianggap lebih efektif karena memiliki akses yang lebih besar dibandingkan dengan off-line WOM. Ulasan mengenai produk yang ditulis oleh konsumen melalui internet dianggap sebagai bentuk komunikasi yang paling penting dalam on-line WOM. Melalui internet khususnya sosial media, konsumen bisa mengungkapkan perasaannya tentang suatu produk secara langsung. Selain itu, sosial media, menyediakan platform bagi konsumen untuk terhubung secara langsung dan real time yang kemudian dapat membangun dan meningkatkan hubungan dengan pelanggan. E-WOM menjadi satu diantara faktor yang efektif dalam memberi pengaruh bagi konsumen hingga berujung pada peningkatan minat beli (Wijaya \& Paramita, 2014).

Lebih lanjut terdapat penelitian sebelumnya yang dilakukan oleh (Imbayani \& Gama, 2018); (Renee B. Kim \& Chao, 2019); (Rose \& Nofiyanti, 2020) dalam penelitiannya menyatakan bahwa citra merek berdampak terhadap minat beli. Selanjutnya, penelitian yang dilakukan oleh (Haratua Pandjaitan, 2018); (Renee B. Kim \& Chao, 2019) mengungkapkan bahwa kesadaran merek juga berdampak terhadap minat beli dan pada penelitian (Anggitasari et al., 2017); (Imbayani \& Gama, 2018); (Laksmi \& Oktafani, 2016); (Tajuddin, Hassan, Othman, \& Razak, 2020) dalam penelitiannya mengungkapkan bahwa E-word of mounth memiliki dampak yang penting terhadap minat beli. 
Penelitian ini penting dilakukan untuk mengetahui variable apa yang mempunyai pengaruh signifikan terhadap Minat Beli Obat Jamu Bejo Jahe Merah.

Ditinjau dari uraian diatas, terdapat fenomena terkait citra merek, kesadaran merek, E-Word Of Mounth terhadap minat beli yang diperkuat dengan adanya penelitian terdahulu. Dengan demikian, penulis akan melakukan penelitian dengan judul "Pengaruh Citra Merek, Kesadaran Merek Dan E-WOM Terhadap Minat Beli Obat Jamu Masuk Angin Bejo Jahe Merah Di Indonesia”.

Penelitian ini memiliki research GAP dari penelitian yang terdahulu yaitu belum ditelitinya Citra Merek, Kesadaran Merek dan E-WOM sebagai variable X terhadap Minat Beli sebagai variable Y yang membahas tentang Obat Jamu.

Terdapat beberapa penelitian terdahulu yang menyatakan bahwa citra merek berpengaruh terhadap minat beli seperti yang dilakukan oleh (Wu et al., 2011); (Imbayani \& Gama, 2018); (Rose \& Nofiyanti, 2020). Demikian juga penelitian terdahulu yang menyatakan bahwa brand awareness memberikan pengaruh pada minat beli seperti yang dilakukan oleh (Dabbous \& Barakat, 2020); (Haratua Pandjaitan, 2018); (Renee B. Kim \& Chao, 2019). Penelitian terdahulu oleh (Wijaya \& Paramita, 2014); (Anggitasari et al., 2017); (Imbayani \& Gama, 2018); (Laksmi \& Oktafani, 2016); (Tajuddin et al., 2020) juga berhasil membuktikan bahwa $e$-WOM berpengaruh terhadap minat beli. Sehingga dapat dirumuskan hipotesis penelitian ini adalah: (1) $\mathrm{H}_{1}$ : Citra merek berpengaruh terhadap minat beli (2) $\mathrm{H}_{2}$ : Kesadaran merek berpengaruh terhadap minat beli (3) $\mathrm{H}_{3}: E$-WOM berpengaruh terhadap minat beli.

\section{Metode Penelitian}

Jenis penelitian yang dilakukan pada penelitian ini adalah penelitian kuantitatif (Sugiyono, 2012). Adapun populasi pada penelitian ini adalah konsumen dan calon konsumen yang akan melakukan pembelian produk Bejo, dikarenakan populasi yang digunakan tidak sedikit maka dilakukakannya pengambilan sampel. Teknik sampling yang digunakan adalah teknik convenience sampling dengan menetapkan sampel sebanyak 385 responden. Metode pengumpulan data yang digunakan dalam penelitian ini adalah dengan e-kuesioner melalui google form yang disebarkan secara online melalui jejaring sosial. Pengisian kuesioner diukur dengan menggunakan skala ordinal dengan urutan rangking dari jenjang terendah hingga tertinggi ataupun sebaliknya. Teknik analisis data diolah menggunakan Partial Least Square (PLS).

\section{Hasil dan Pembahasan}

\section{A. Gambaran Umum}

Satu diantara anak perusahaan paling besar dari PT. Kalbe Farma Group adalah PT. Bintang Toedjo. Tahun 1974, Bintang Toedjo memulai untuk produksi obat resep dokter (ethical) karena minat konsumen terhadap jenis obat semakin bermacam-macam. Semakin banyaknya ahli farmasi juga mendukung kemajuan produksi perusahaan. Tepat pada tahun 1985, Kalbe Farma mengakuisisi Bintang Toedjo. Hal ini menjadikan bisnis Bintang Toedjo semakin berkembang. Bintang 
Toedjo menyasar kalangan menengah ke bawah yang memerlukan obat berkualitas dan harga ekonomis (merdeka.com, 2020).

Kalbe melalaui anak usaha PT. Bintang Toedjoe bekerjasama dengan Badan Narkotika Nasional (BNN) Republik Indonesia untuk memberantas narkoba. Tujuan tersebut direalisasikan dengan berhasilnya perusahaan dalam memberdayakan jahe merah di wilayah rawan narkoba. Kemudian, jahe ini diedarkan menggunakan merek Bejo Jahe Merah dan menjadi jamu masuk angin pertama dengan aroma terapi di Indonesia.

\section{B. Karakteristik Konsumen}

Dalam penelitian ini, mayoritas konsumen dan calon konsumen produk Bejo jahe merah didominasi oleh laki-laki yang dimana kebanyakan dari mereka berusia lebih dari 36 tahun. Konsumen dan calon konsumen produk Bejo jahe merah juga didominasi oleh mereka yang berasal dari Pulau Jawa dengan mayoritas pekerjaan sebagai pegawai negeri atau swasta yang memiliki rata-rata pendapatan lebih dari Rp. 3.000.000.

\section{Uji Validitas}

Pada model indikator formatif, hasil output VIF menunjukkan bahwa nilai VIF masing-masing pernyataan pada variabel citra merek menunjukkan nilai $<5$, artinya setiap butir pernyataan citra merek telah valid. Pada model indikator reflektif, variabel tentang E-wom, kesadaran merek dan minat beli adalah valid dikarenakan telah mencukupi syarat Average Variance Extracted (AVE) diatas 0,50.

\section{Uji Reliabilitas}

Pada model indikator Formatif, nilai rata-rata outer weight pada variable citra merek dinyatakan valid karena >0,70. Demikian juga pada model indikator reflektif, hasil cronbach's alpha pada variabel variable E-wom, kesadaran merek dan minat beli dinyatakan valid karena $>0,70$. Sehingga kesimpulannya semua variabel reliabel terhadap masing-masing konstruknya.

\section{E. Uji Koefisien Determinasi $\left(\mathbf{R}^{2}\right)$}

Tahap berikutnya ketika butir pernyataan setiap variabel dinyatakan valid, semua variable tersebut dinyatakan reliable. Selanjutnya pengujian model structural penelitian dengan uji R Square.

Tabel 2

Nilai R-Square

\begin{tabular}{cl}
\hline \multicolumn{1}{c}{ Keterangan } & R-Square \\
\hline Minat Beli & 0.886 \\
\hline
\end{tabular}

Sumber: Hasil Output PLS 3.2.7

Menurut table di atas, dapat diketahui besarnya nilai R Square (R2) Minat beli 0,804 yang menunjukan bahwa kontribusi dari variabel Citra merek, kesadaran merek dan E-Wom pada minat beli sebesar 0,886 atau 88,6\%, sisanya $11.4 \%$ 
kontribusi terhadap variabel Minat Beli adalah oleh variabel lain seperti Harga, Keunggulan Produk, Promosi, Atmosfer Toko dan lainya.

\section{F. Uji Hipotesis}

Ketika semua butir pernyataan setiap variabel valid, seluruh variable dan model structural penelitian dinyatakan reliable dan fit langkah berikutnya adalah melaksanakan uji t-statistik penelitian. Tujuan dilakukannya uji t-statistk menggunakan uji t atau uji parsial sebagai langkah untuk mengetahui pengaruh antara Citra Merek $\left(\mathrm{X}_{1}\right)$, Kesadaran Merek $\left(\mathrm{X}_{2}\right)$ dan E-Word Of Mouth $\left(\mathrm{X}_{3}\right)$ pada Minat Beli (Y). Menurut Sarjono \& Julianita (2011, hlm. 133) untuk mencari nilai $\mathrm{t}_{\text {tabel }}$ dilihat dari taraf signifikansi 0,05 dimana $\mathrm{df}=$ jumlah sampel - jumlah variabel. Maka diketahui $\mathrm{t}_{\text {tabel }}=1,966$ didapat dari rumus $\mathrm{df}=\mathrm{N}-\mathrm{K}$ atau $\mathrm{df}=385-4=381$, selanjutnya penghubungan dengan derajat kesalahan 5\% atau 0,05. Menurut pengelolaan data uji signifikansi (Uji t), didapatkan hasil seperti pada tabel berikut:

Tabel 3

Uji Statistik

\begin{tabular}{lrrr}
\hline Path Coefficients & Original Sample & T Statistic & P Value \\
\hline Citra Merek -> Minat Beli & 0.587 & 10.996 & 0.000 \\
\hline E-WOM -> Minat Beli & 0.366 & 7.664 & 0.000 \\
\hline Kesadaran Merek -> Minat Beli & 0.012 & 0.279 & 0.780 \\
\hline
\end{tabular}

Sumber: Hasil dari SmartPLS 3.2.7

Menurut tabel di atas, bisa diketahui bahwa hasil pengaruh variabel citra merek pada minat beli mengindikasikan nilai $t_{\text {hitung }} 10.996>t_{\text {tabel }} 1,966$ dan nilai $P$ Value sebesar $0,000<0,05$. Hal tersebut mengindikasikan bahwa Citra merek memiliki pengaruh terhadap Minat Beli. Kesimpulannya Citra Merek memiliki pengaruh yang signifikan terhadap Minat Beli atau dapat dikatan H1 diterima.

Tabel di atas juga menunjukkan hasil pengaruh variabel kesadaran merek atas Minat Beli memperlihatkan nilai $\mathrm{t}_{\text {hitung }} 0.279<\mathrm{t}_{\text {tabel }} 1,966$ dan nilai $\mathrm{P}$ Value sebesar $0,780>0,05$. Hal tersebut mengindikasikan kesadaran merek tidak memiliki pengaruh pada Minat Beli atau dapat dikatan $\mathrm{H} 2$ ditolak.

Melalui table di atas, dapat dipahami bahwa hasil pengaruh variabel $E$-Word Of Mouth pada Minat Beli memperlihatkan nilai $\mathrm{t}_{\text {hitung }} 7.664>\mathrm{t}_{\text {tabel }} 1,966$ dan nilai $\mathrm{P}$ Value sebesar $0,000<0,05$. Dari data tersebut megindikasikan bahwa E-Word Of Mouth memiliki pengaruh yang penting pada Minat Beli dan dapat dikatakan H3 diterima.

Adapun dominasi positif antara variabel Citra merek pada Minat Beli dalam original sampel memiliki nilai 0.587, pada variable kesadaran merek dalam original sampel memiliki nilai 0.012 dan E-Word Of Mouth terhadap Minat Beli dalam original sampel memiliki nilai sebesar 0.366 yang artinya apabila Citra Merek, Kesadaran Merek dan E-Word Of Mouth baik maka Minat Beli akan meningkat. 


\section{G. Citra Merek Berkenaan dengan Minat Beli Obat Jamu Masuk Angin Bejo Jahe Merah Di Indonesia}

Menurut data dari penelitian ini hasil pengujian hipotesis membuktikan Citra Merek dapat meningkatkan Minat Beli Obat Jamu Masuk Angin Bejo Jahe Merah Di Indonesia sebesar $57.7 \%$ dengan kata lain tingkat yang baik dari citra merek dari produk akan mengakibatkan Minat Beli konsumen Obat Jamu Masuk Angin Bejo Jahe Merah Di Indonesia dalam bentuk produk yang dijual di pasaran sudah memiliki merek, oleh karena itu merek dapat digunakan untuk penanda atau pembeda antara produk yang satu dengan yang lainnya.

Hal tersebut mengartikan bahwa konsumen Obat Jamu Masuk Angin Bejo Jahe Merah menyadari bahwa Aroma Produk Bintang Toedjoe Masuk Angin sangat enak di lidah dan tenggorokan serta Produk Bintang Toedjoe Masuk Angin memiliki desain dan warna kemasan yang menarik dan juga terjamin kualitasnya. Dari berbagai kriteria Citra merek yang diberikan yaitu dengan rasa, kemasan, kualitas dan mutu, kegunaan dan manfaat, harga dan image Obat Jamu Masuk Angin Bejo Jahe Merah Di Indonesia. Dalam mempertahankan citra merek Obat Jamu Masuk Angin Bejo Jahe Merah Di Indonesia di setiap wilayah Indonesia sangat memperhatikan kebutuhkan pelanggannya. Dengan citra merek yang unggul maka banyak pelanggan yang akan bertahan untuk berkerja sama dalam penggunaan Obat Jamu Masuk Angin Bejo Jahe Merah Di Indonesia sehingga dapat meningkatkan keinginan untuk membeli dari konsumen.

Sehingga Citra merek di produk Obat Jamu Masuk Angin Bejo Jahe Merah Di Indonesia adalah keyakinan konsumen terhadap nama produk dan kesan dari konsumen terhadap merek produk tersebut menurut informasi dan fakta-fakta yang ada, lalu penggunaan dari merek itu yang mengakibatkan kesan yang terbentuk dalam benak konsumen ini relatif jangka panjang.

Hal ini sama seperti penelitian yang dilakukan oleh Kurniawan, et.al. (2018) menyatakan citra merek dapat memberikan manfaat yang baik terhadap minat beli dengan citra positif yang dimiliki konsumen memungkinkan terjadinya pembelian, citra postif tersebut dapat digunakan oleh perusahaan dalam pengembangan lini produk yang sudah terbentuk pada produk merek lama, bahkan strategi family branding dan leverage branding bisa dilakukan ketika sudah adanya citra merek produk yang baik.

(Khoshsorour \& Gilaninia, 2018) menyatakan dalam pembuatan minat pembeli, Citra merek sebagai syarat ekstrinsik yang sering digunakan. Jika dalam hal pembelian suatu produk konsumen cenderung membeli produk yang mereknya sudah di sukai atau terkenal jika konsumen kurang berpengalaman pada suatu produk dan membeli produk yang sudah mendapatkan citra positif atau disukai bisa mengurangi resiko saat membeli barang. Citra merek suatu prduk seringkali digunakan oleh konsumen sebagai salah satu pertimbagan dalam membangun minat pembelian sebuah produk. 
Hasil penelitian yang menyimpulkan bahwa citra merek dapat meningkatkan Minat Beli diantaranya menurut penelitian yang telah dilakukan oleh (Imbayani \& Gama, 2018); (Renee B. Kim \& Chao, 2019); (Rose \& Nofiyanti, 2020) menyatakan citra merek berpengaruh cukup signifikan terhadap Minat Beli. Citra merek perpengaruh kuat terhadap kualitas yang unggul dibandingkan produk lainnya. Dengan kualitas yang unggul akan membuat konsumen tidak akan ragu untuk membeli suatu produk.

\section{H. Kesadaran Merek Terhadap Minat Beli Obat Jamu Masuk Angin Bejo Jahe Merah Di Indonesia}

Pada penelitian ini megindikasikan bahwa hasil pengujian hipotesis menunjukan Kesadaran Merek tidak dapat meningkatkan Minat Beli Obat Jamu Masuk Angin Bejo Jahe Merah Di Indonesia hanya sebesar 1.2\% oleh karena itu jika semakin baik kesadaran merek yang diberikan maka Minat Beli konsumen Obat Jamu Masuk Angin Bejo Jahe Merah di Indonesia dalam meyakinkan konsumen dalam mengingat dan mengenali merek produk yang dijual maka merek tersebut antara satu produk dengan produk yang lain dapat dijadikan sebagai pembeda.

Hal tersebut mengartikan bahwa konsumen Obat Jamu Masuk Angin Bejo Jahe Merah Di Indonesia menyadari bahwa merek yang muncul pertama kali di benak saat membeli obat masuk angin bukanlah produk Bejo Jahe Merah melainkan produk lainnya, Produk Bejo Jahe Merah obat masuk angin pertama yang menawarkan aroma kuat dibandingkan produk sejenisnya dan Produk Bejo Jahe Merah merupakan obat masuk angin yang pertama kali muncul di benak pikiran konsumen. Dari berbagai kriteria kesadaran merek yang diberikan yaitu dengan rasa, kemasan, kualitas dan mutu, kegunaan dan manfaat, harga dan image Obat Jamu Masuk Angin Bejo Jahe Merah di Indonesia. Dalam mempertahankan kesadaran merek Obat Jamu Masuk Angin Bejo Jahe Merah Di Indonesia di setiap wilayah Indonesia sangat memperhatikan kebutuhkan pelanggannya. Dengan kesadaran merek yang unggul maka banyak pelanggan yang akan bertahan untuk berkerja sama dalam penggunaan Obat Jamu Masuk Angin Bejo Jahe Merah Di Indonesia sehingga dapat meningkatkan minat beli konsumen. Sehingga Kesadaran merek pada produk Obat Jamu Masuk Angin Bejo Jahe Merah adalah ketika konsumen dapat mengingat merek dalam kondisi yang berbeda seperti halnya prestasi dan pengenalan merek Obat Jamu Masuk Angin Bejo Jahe Merah.

Pada penelitian ini tidak sejalan dengan (Ramadayanti, 2019) yang menyatakan bahwa 'Kesadaran merek adalah kesanggupan seorang calon pembeli untuk mengenali atau mengingat kembali bahwa suatu merek merupakan bagian dari kategori produk tertentu'. Dengan arti keahlian konsumen saat mengidentifikasi atau mengingat ingat merek dari suatu produk tersebut. Kesadaran merek terletak diantara perasaan kurang yakin terhadap pengenalan suatu merek sampai dengan perasaan yakni dalam kelas produk yang bersangkutan produk tersebut merupakan 
satu-satunya. Apabila seorang konsumen sudah mengingat suatu produk kemungkinan besar konsumen tidak akan berpaling ke produk lain

Hasil penelitian menyimpulkan bahwa kesadaran Merek tidak dapat meningkatkan Minat Beli. Namun hal tersebut tidak sama dengan penelitian yang dilakukan oleh (Anggitasari et al., 2017); (Saidani \& Arifin, 2012); (Haratua Pandjaitan, 2018); (Renee B. Kim \& Chao, 2019) yang dalam penelitiannya menyatakan bahwa kesadaran merek dapat mempengaruhi minat beli. Kesadaran merek berpengaruh kuat pada pengenalan dan penginatan merek dibandingkan produk lainnya.

\section{E-Word Of Mouth Terhadap Minat Beli Obat Jamu Masuk Angin Bejo Jahe} Merah Di Indonesia

Berdasarkan penelitian ini hasil dari pengujian hipotesis menunjukan E-Word Of Mouth dapat meningkatkan Minat Beli Obat Jamu Masuk Angin Bejo Jahe Merah sebesar 36,6\% artinya tingkat yang baik dari E-Word Of Mouth yang diberikan maka Minat Beli konsumen Obat Jamu Masuk Angin Bejo Jahe Merah Di Indonesia. Hal ini dikarenakan banyaknya rekomendasi serta dorongan untuk menggunakan produk tersebut pada saat sedang masuk angin.

Hal tersebut mengartikan bahwa konsumen Obat Jamu Masuk Angin Bejo Jahe Merah menyadari bahwa banyak konsumen yang merekomendasikan kepada orang-orang terdekat yang butuh informasi serta manfaat atau khasiatnya terkait Produk Bejo Jahe Merah. Dari berbagai kriteria E-Word Of Mouth yang diberikan yaitu kemauan konsumen membicarakan produk, merekomendasi produk kepada orang lain dan dorongan dari teman atau relasi. Dalam mempertahankan E-Word Of Mouth Obat Jamu Masuk Angin Bejo Jahe Merah seringnya informasi positif yang didengar konsumen dari pembicaraan dan rekomendasi teman, menjadikan konsumen memiliki motivasi untuk selalu menggunakan produk Bejo Jahe Merah masuk angin dan konsumen termotivasi untuk menggunakan produk Bejo Jahe Merah masuk angin karena adanya seseorang yang memberi informasi dan mengajak untuk sehat bersama-sama sehingga dapat meningkatkan minat beli konsumen.

Penelitian ini berada pada jalur yang sama dengan penelitian dari (Juniantoko, 2017) menyatakan adanya perbincangan atau informasi yang berasal dari mulut ke mulut dapat memperngaruhi perilaku konsumen dalam hal membeli produk. Penyebab dari Word of mouth adalah kebutuhan konsumen yang berkaitan dengan mengirim dan menerima informasi. Kebanyakan calon konsumen kemungkinan lebih mempercayai informasi yang berasal dari mulut kemulut dikarenakan sudah menurunnya kepercayaan konsumen terhadap iklan perusahaan, ntuk mengurangi resiko ketidakpuasan pada suatu prosuk mereka menggali informasi sendiri.

Hasil ini sependapat dengan (Jalilvand, Samiei, Dini, \& Manzari, 2012), terjadinya rekomendasi ataupun memperlihatkan produk dari konsumen lain seperti menyebarkan review pada sebuah perkumpulan atau platform dapat berpengaruh pada minat beli konsumen. Jika setiap konsumen melakukan word of mouth yang 
berefek pada pemberian pilihan secara tidak langsung kepada konsumen lain hal ini akan membuat orang lain tersebut tertarik kepada prosuk yang di review. Pada dasarnya informasi dan saran sebuah produk dari konsumen lain yang sudah pernah membeli atau memakai dapat menciptakan minat beli konsumen. Hal ini bisa mendorong konsumen untuk membeli produk tersebut.

Hasil penelitian yang menyimpulkan bahwa E-Word Of Mouth dapat meningkatkan Minat Beli diantaranya penelitian yang pernah dilakukan (Anggitasari et al., 2017); (Imbayani \& Gama, 2018); (Laksmi \& Oktafani, 2016); (Tajuddin et al., 2020); (Fungkiya Sari \& Edriana Pangestuti, 2018) yang mana menyatakan bahwa E-Word Of Mouth memiliki pengaruh yang cukup signifikan pada Minat Beli. E-Word Of Mouth memiliki pengaruh kuat terhadap rekomendasi yang tepat dibandingkan produk lainnya. Dengan melalui rekomendasi dari orang terdekat hal tersebut dapat mudah di percaya dalam pemilihan obat masuk angin yaitu produk Bejo Jahe Merah.

\section{Kesimpulan}

Menurut penelitian yang sudah dilaksanakan, hasil analisis dan pembahasan yang sudah dijelaskan pada bab-bab sebelumnya berkenaan mengenai pengaruh Citra Merek, Kesadaran merek dan e- word of mouth terhadap Minat pembelian Obat Jamu Masuk Angin Bejo Jahe Merah Di Indonesia serta pengujian yang telah dilakukan dapat ditarik kesimpulan bahwa: a). Citra Merek bisa berpengaruh dengan signifikan terhadap Minat Beli Obat Jamu Masuk Angin Bejo Jahe Merah. b). Kesadaran Merek tidak cukup memiliki pengaruh secara signifikan terhadap Minat Beli Obat Jamu Masuk Angin Bejo Jahe Merah. c). E-word of mouth dapat dikatakan memiliki pengaruh signifikan pada Minat Beli Obat Jamu Masuk Angin Bejo Jahe Merah. 


\section{BIBLIOGRAFI}

Anggitasari, Siti Rafi, Hurriyati, Ratih, \& Wibowo, Lili Adi. (2017). Pengaruh Electronic Word of Mouth Terhadap Pengetahuan Konsumen Serta Dampaknya Terhadap Minat Beli Online. Jurnal Ilmu Manajemen Dan Bisnis, 8(1), 6. https://doi.org/10.17509/jimb.v8i1.12655 Google Scholar

Dabbous, Amal, \& Barakat, Karine Aoun. (2020). Bridging the online offline gap: Assessing the impact of brands' social network content quality on brand awareness and purchase intention. Journal of Retailing and Consumer Services, 53(November 2018), 101966. https://doi.org/10.1016/j.jretconser.2019.101966 Google Scholar

Duarte, Paulo, Costa e Silva, Susana, \& Ferreira, Margarida Bernardo. (2018). How convenient is it? Delivering online shopping convenience to enhance customer satisfaction and encourage e-WOM. Journal of Retailing and Consumer Services, 44(June), 161-169. https://doi.org/10.1016/j.jretconser.2018.06.007 Google Scholar

Fungkiya Sari, \& Edriana Pangestuti. (2018). Pengaruh Electronic Word of Mouth (EWom) terhadap Minat Berkunjung dan Keputusan Berkunjung (Studi pada Wisata Coban Rais BKPH Pujon). Jurnal Administrasi Bisnis, 54(1), 189-196. Google Scholar

Graciola, Ana Paula, De Toni, Deonir, Milan, Gabriel Sperandio, \& Eberle, Luciene. (2020). Mediated-moderated effects: High and low store image, brand awareness, perceived value from mini and supermarkets retail stores. Journal of Retailing and $\begin{array}{lll}\text { Consumer } & \text { Services, } & \text { 55(March), }\end{array}$ https://doi.org/10.1016/j.jretconser.2020.102117 Google Scholar

Haratua Pandjaitan, D. R. (2018). An Analysis of Brand Awareness Influence on Purchase Intention in Bandar Lampung City's Online Transportation Service (Study on Y Generation Consumers). KnE Social Sciences, 3(10), 1-14. https://doi.org/10.18502/kss.v3i10.3418 Google Scholar

Imbayani, I. Gusti Ayu, \& Gama, Agus Wahyudi Salasa. (2018). The Influence of Electronic Word of Mouth (E-Wom), Brand Image, Product Knowledge on Purchase Intention. Jurnal Ekonomi \& Bisnis JAGADITHA, 5(2), 145-153. Google Scholar

Iskandar, Senkli Martin, \& Mustamu, Ronny H. (2018). Strategi Bersaing Pada Perusahaan Distribusi Consumer Goods Dalam Mencapai Keunggulan Kompetitif. Agora, 6(1), 1-6. Google Scholar

Jalilvand, Mohammad Reza, Samiei, Neda, Dini, Behrooz, \& Manzari, Parisa Yaghoubi. (2012). Examining the structural relationships of electronic word of mouth, destination image, tourist attitude toward destination and travel intention: An integrated approach. Journal of Destination Marketing \& Management, 1(1-2), 134-143. Google Scholar 
Juniantoko, Ardy Dwi. (n.d.). Supriono.(2017, Desember). Pengaruh Word Of Mouth Terhadap Minat Beli Serta Dampaknya Pada Keputusan Pembelian. Jurnal Administrasi Bisnis, 53(2), 11-18. Google Scholar

Kabaressy, M., \& DW, H. (2017). Pengaruh Kualitas Produk, Iklan, Dan, Citra Merek (Brand Image) Terhadap Keputusan Penggunaan Tolak Angin (Studi Kasus Pada Pengguna Tolak Angin Di Kota Semarang). Jurnal Ilmu Administrasi Bisnis S1 Undip, 6(4), 327-333. Google Scholar

Khoshsorour, Ashkan, \& Gilaninia, Shahram. (2018). The Impact Of Knowledge Management Components On The Performance Of Cultural, Arts And Media Institutions. Kuwait Chapter of the Arabian Journal of Business and Management Review, 7(3), 1-4. Google Scholar

Kim, Renee B., \& Chao, Yan. (2019). Effects of brand experience, brand image and brand trust on brand building process: The case of chinese millennial generation consumers. Journal of International Studies, 12(3), 9-21. https://doi.org/10.14254/2071-8330.2019/12-3/1 Google Scholar

Kim, Seongseop (Sam), Choe, Ja Young (Jacey), \& Petrick, James F. (2018). The effect of celebrity on brand awareness, perceived quality, brand image, brand loyalty, and destination attachment to a literary festival. Journal of Destination Marketing and Management, 9(November 2016), 320-329. https://doi.org/10.1016/j.jdmm.2018.03.006 Google Scholar

Kotler, Philip, \& Keller, Kevin Lane. (2016). Marketing Management (15th ed.). Pearson Education,Inc. Google Scholar

Laksmi, Aditya Ayu, \& Oktafani, Farah. (2016). Pengaruh Electronic Word Of Mouth (Ewom) Terhadap Minat Beli Followers Instagram Pada Warunk Upnormal. Jurnal Computech \& Bisnis, 10(2), 78-88. Google Scholar

Mardalena, Novi Tria, Lubis, A. Rahman, \& Utami, Sorayanti. (2018). Pengaruh Kesadaran Merek, Kepercayaan Merek Dan Keunggulan Produk Terhadap Minat Beli Produk Luxuri Fashion Brand Dengan Gender Sebagai Moderating Pada Pemasaran Media Sosial Di Kota Banda Aceh. Jurnal Magister Manajemen, 2(1), 99-114. Google Scholar

Park, Jungkun, Hyun, Hyowon, \& Thavisay, Toulany. (2021). A study of antecedents and outcomes of social media WOM towards luxury brand purchase intention. Journal of Retailing and Consumer Services, 58(September 2020), 102272. https://doi.org/10.1016/j.jretconser.2020.102272 Google Scholar

Ramadayanti, Firda. (2019). Peran brand awereness terhadap keputusan pembelian produk. Jurnal Studi Manajemen Dan Bisnis, 6(2), 111-116. Google Scholar

Rose, Tipri, \& Nofiyanti, Fifi. (2020). Citra Merek Terhadap Minat Beli Konsumen 
Pengaruh Citra Merek, Kesadaran Merek dan E-Wom Terhadap Minat Beli Obat Jamu Masuk Angin Bejo Jahe Merah Di Indonesia

Kopi Kekinian di Jakarta. Literatus, 2(1), 40-51. https://doi.org/10.37010/lit.v2i1.33 Google Scholar

Saidani, Basrah, \& Arifin, Samsul. (2012). Pengaruh kualitas produk dan kualitas layanan terhadap kepuasan konsumen dan minat beli pada ranch market. Jurnal Riset Manajemen Sains Indonesia, 3(1), 1-22. Google Scholar

Sugiyono. (2012). Metode Penelitian Kuantitatif Kualitatif \& RND. Bandung: Alfabet.

Tajuddin, Uwais Nor Rifhan Ahmad, Hassan, Lailatul Faizah Abu, Othman, Abdul Kadir, \& Razak, Norfadzilah Abdul. (2020). Electronic word-of-mouth (E-WOM), brand image and consumer purchase intention on healthcare products. Journal of Accounting Research, Organization and Economics, 3(1), 73-83. Google Scholar

Wijaya, Tommi, \& Paramita, Eristia Lidia. (2014). Pengaruh Electronic Word of Mouth (E-WoM) terhadap Keputusan Pembelian Kamera DSLR. Seminar Nasional Dan Call for Paper, (978-602-70429-1-9), 12-19. Google Scholar

Wu, Paul C. S., Yeh, Gary Yeong Yuh, \& Hsiao, Chieh Ru. (2011). The effect of store image and service quality on brand image and purchase intention for private label brands. Australasian Marketing Journal, 19(1), 30-39. https://doi.org/10.1016/j.ausmj.2010.11.001 Google Scholar

\section{Copyright holder:}

Christarevy Renaputra Hosfiar, Miguna Astuti, Acim Heri Iswanto (2021)

First publication right:

Syntax Literate: Jurnal Ilmiah Indonesia

This article is licensed under:

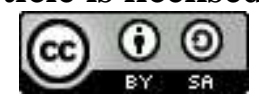

